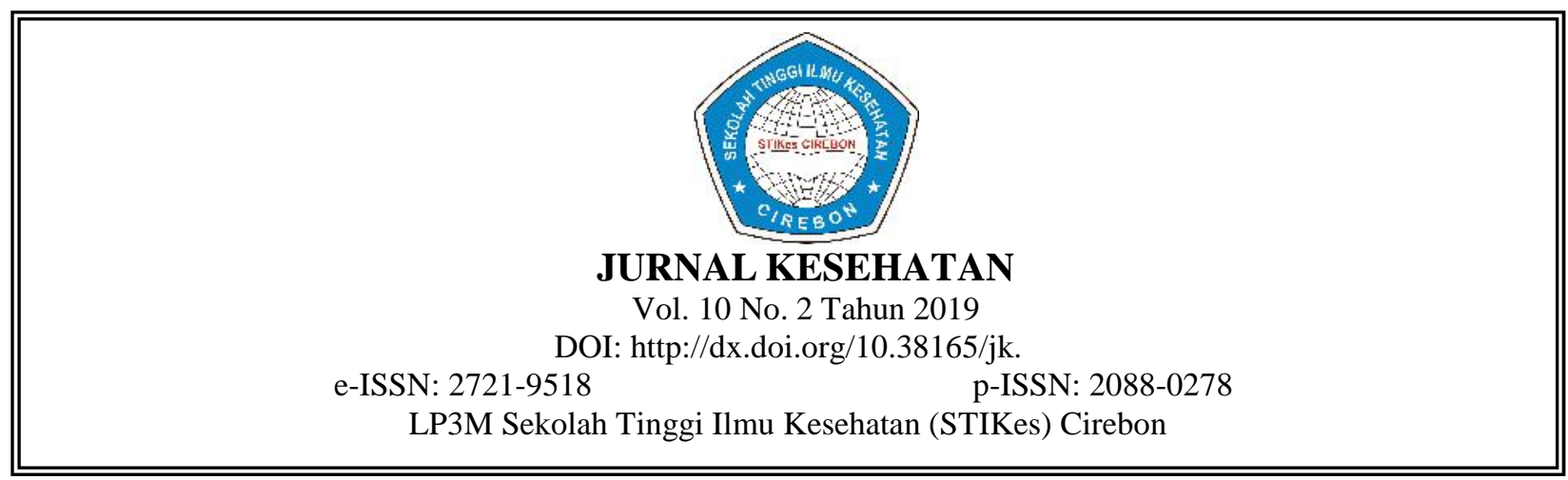

\title{
PENGARUH KONSELING PERSONAL TERHADAP PERILAKU PENCEGAHAN PENULARAN TB PARU
}

\author{
Uun Kurniasih* \\ Program Studi Ilmu Keperawatan Sekolah Tinggi Ilmu Kesehatan Cirebon \\ arshaq.rafasya@gmail.com \\ Arif Rakhmat** \\ Program Studi Ilmu Keperawatan Sekolah Tinggi Ilmu Kesehatan Cirebon
}

\begin{abstract}
Abstrak
Tuberkulosis adalah penyakit infeksi yang disebabkan oleh Mycrobacterium Tuberculosis. Tuberkulosis disebabkan oleh bakteri atau kuman Mycrobacterium Tuberculosis.Kuman ini mudah menular lewat udara sehingga penyakit ini sering dikaitkan dengan penyakit paru walaupun sebenarnya kuman ini tidak hanya menyerang paru-paru saja.Tujuan penelitian ini adalah untuk mengetahui perubahan perilaku sebelum dan sesudah diberikan konseling personal terhadap perilaku pencegahan penularan TB paru di Wilayah Kerja UPT Puskesmas Plumbon Kabupaten Cirebon. Desain penelitian ini quasi eksperimen yang digunakan adalah one group Pretest Postest. Subyek penelitian ini adalah penderita TB paru di Wilayah Kerja UPT Puskesmas Plumbon Kabupaten Cirebon tahun 2019. Teknik pengambilan sampel dengan menggunakan total sampel dengan jumlah 24 responden. Instrumen penelitian yang digunakan berupa lembar angket perilaku pencegahan penularan TB paru. Metode analisa data yang digunakan adalah uji paired t test. Hasil penelitian menunjukan bahwa sebelum diberikan konseling personal dengan niali rata-rata $66,7 \%$ dengan kategori perilaku pencegahan penularan rendah, dan sesudah diberikan konseling personal didapatkan hasil nilai rata-rata $100 \%$ dengan kategori memiliki perilaku tinggi terhadap perilaku pencegahan penularan TB paru. Dari uji paired t test didapatkan nilai $p$ value adalah signifikan $0,000(a<0,05)$. Sehingga dapat disimpulkan bahwa ada pengaruh konseling personal terhadap perilaku pencegahan penularan TB paru di Wilayah Kerja UPT Puskesmas Plumbon Kabupaten Cirebon Tahun 2019.
\end{abstract}

Kata Kunci: Konseling Personal, TB Paru, Perilaku Pencegahan Penularan

\begin{abstract}
Tuberculosis is an infectious disease caused by Mycrobacterium Tuberculosis. Tuberculosis is caused by bacteria or Mycrobacterium Tuberculosis bacteria. This bacterium is easily transmitted through the air so that the disease is often associated with lung disease even though these germs do not only attack the lungs. The purpose of this study is to knowing changes in behavior before and after personal counseling on the prevention behavior of pulmonary TB transmission in the Work Area of the UPT Plumbon Health Center in Cirebon Regency. The design of this quasiexperimental study used was one group pretest posttest. The subjects of this study were pulmonary TB patients in the Work Area of the UPT Plumbon Public Health Center in Cirebon Regency in 2019. The sampling technique used a total sample of 24 respondents. The research instruments used were questionnaires. prevention behavior of pulmonary TB transmission. The data analysis used is the paired t test. The results showed that before being given personal counseling with an average score of $66.7 \%$ with the category of low transmission prevention behavior, and after being given personal counseling the results of the average score were 100\% with the category having high behavior towards the prevention behavior of pulmonary TB transmission. The statistical test results obtained with a significant value of 0,00 can be concluded that there is an effect of personal counseling on the prevention behavior of pulmonary $T B$ transmission in the Work Area of the Cirebon District Plumbon Public Health Unit in 2019.
\end{abstract}

Keywords: Personal Counseling, Pulmonary TB, Behavior Prevention of Transmission 


\section{PENDAHULUAN}

Tuberkulosis masih menjadi permasalahan utama kesehatan masyarakat, selain mempengaruhi produktivitas kerja masyarakat, juga merupakan penyebab utama kematian. ${ }^{1}$ Tuberkulosis merupakan salah satu jenis penyakit generatif yang menyerang kelompok produktif maupun anak-anak dan merupakan penyakit paling menular. Sumber penularannya adalah pasien TB, terutama pasien yang mengandung kuman TB dalam dahaknya. Pada waktu batuk atau bersin, pasien menyebarkan kuman ke udara dalam bentuk percikan dahak (droplet nuclei/percik renik). ${ }^{2}$

Tuberkulosis sangat berbahaya karena bisa menyebabkan seseorang bisa meninggal dan sangat mudah ditularkan kepada siapa saja dimana satu orang pasien Tuberkulosis dengan Baksil Tahan Asam (BTA) positif bisa menularkan kepada 10-15 orang di sekitarnya setiap tahun. ${ }^{3}$

Menurut Profil Kesehatan Jawa Barat 2016, jumlah pasien TB paru yang di temukan dan tercatat dalam laporan berdasarkan kabupaten/kota per 100.000 penduduk, antara 35,25/100.000 (Kabupaten Subang), hingga 428,68 (Kota Cirebon) dengan rata-rata 136,13, terdapat 14 kabupaten /kota dengan CNR dibawah Jawa Barat (12,58), yaitu Kab Subang, Kab Indramayu, Kab Pangandaran, Kab Tasikmalaya, Kota Bandung, Kab Garut, Kota Cimahi, dan Kab Ciamis. ${ }^{5}$ Dengan keterangan total banyaknya pasien tuberkulosis di Jawa Barat pada tahun 2016 sebanyak 52,328 orang dengan rincian 29,429 laki-laki dan 22,899 perempuan. $^{4}$

Tuberkulosis (TB) sampai saat ini masih merupakan salah satu masalah kesehatan masyarakat di dunia walaupun upaya penanggulangan TB telah dilaksanakan di banyak negara sejak tahun 1995. Menurut laporan WHO tahun 2017, di tingkat global diperkirakan 10.900.000 kasus TB baru dengan 3,2 juta kasus diantaranya adalah perempuan, dan 1.400.000 juta kematian karena TB paru. Dari kasus TB paru tersebut ditemukan 1.170.000 (12\%) HIV positif dengan kematian 190.000 orang. Dari 9,6 juta kasus TB baru, diperkirakan 1 juta kasus TB anak (dibawah usia 15 tahun) dan 140.000 kematian /tahun. ${ }^{5}$

Jumlah Kasus TB Paru di Indonesia di perkirakan ada 1.020.000 kasus TB baru pertahun (399 per 100.000 penduduk) dengan 100.000 kematian pertahun (41 per 100.000 penduduk). Diperkirakan 78.000 kasus TB dengan HIV positif (10 per 100.000 penduduk), mortalitas 26.000). Jumlah seluruh kasus 324.539 kasus, diantaranya 314.965 adalah kasus baru. Secara nasional perkirakan pravelensi HIV diantara pasien TB diperkirakan sebanyak 6,2\%. Jumlah kasus TB-RO dari kasus baru TB dan ada $12 \%$ kasus TB -RO dari TB dengan pengobatan ulang. ${ }^{5}$

Salah satu cara yang bisa digunakan untuk pencegahan penularan TB paru yaitu konseling kesehatan yang dilakukan oleh konselor secara personal. Konseling kesehatan secara personal di disain untuk menolong pasien TB paru dalam memahamai dan menjelaskan pandangan terhadap suatu masalah yang sedang dihadapi melalui pemecahan masalah, pemahaman karakter, dan prilaku kesehatan pasien. ${ }^{5}$ Konseling sendiri merupakan proses pemberian bantuan yang dilakukan melalui wawancara dan teknik perubahan tingkah laku lainnya oleh seorang ahli atau konselor kepada individu yang sedang menghadapi masalah yang berfokus pada teratasinya masalah yang dihadapi klien. Dengan teratasinya masalah yang dihadapi akan membangkitkan semangat dan gaya berprilaku yang lebih baik pada diri klien sehingga dengan dilaksanakannya konseling diharapkan akan membahagiakan diri klien dan lingkungannya. ${ }^{6}$

Konseling personal pada dasarnya memiliki tujuan akhir yakni perubahan perilaku terhadap seseorang atau individu. Perubahan yang dimaksud yaitu perubahan menuju kearah yang lebih baik/konstruktif dan positif. Konselor yang datang kepada klien biasanya menemui klien dalam keadaan yang cenderung bersifat destruktif, tidak stabil serta tidak bisa memahami dirinya dan bertindak yang tidak semestinya sehingga cara berpikirnya pun irasional. Akibat yang disebabkan dari cara berpikir yang irasional disini peran konselor diperlukan untuk membantu klien memahami dirinya serta bisa bertindak yang semestinya (ada kesadaran) sehingga klien bisa mengubah perilaku irasionalnya menjadi rasional kembali. ${ }^{7}$

Perubahan tingkah laku tidak hanya ditandai pada cara perubahan cara menghafal dan mengingat. Perubahan tersebut ditandai dengan ada perubahan tingkah laku pada diri klien yang berbeda dengan kebiasaannya. Seperti perubahan pengetahuan, perubahan pemahaman, dan 
sikapnya. Selain itu juga tampak dari kecakapan, kemampuan, daya reaksi, keterampilan dan penerimaan dari individu yang bersangkutan. Jadi, perubahan perilaku merupakan proses yang aktif dan bereaksi dalam semua situasi yang ada pada diri klien. ${ }^{7}$ Tujuan penelitian adalah untuk mengetahui pengaruh konseling personal terhadap perilaku pencegahan penularan TB paru di Wilayah Kerja UPT Puskesmas Plumbon Kabupaten Cirebon tahun 2019.

\section{METODE PENELITIAN}

Desain penelitian quasi eksperimen yang digunakan adalah one group pretest postest yaitu eksperimen yang dilaksanakan pada kelompok saja tanpa kelompok perbandingan. Penelitian ini dilakukan dengan cara melakuakan pretest (01) sebelum penerapan konseling personal dan melakukan postest (02) setelah penerapan konseling personal. Impelementasi dilakukan sebanyak empat kali pertemuan. Populasi adalah penderita TB Paru di Wilayah Kerja UPT Puskesmas Plumbon Kabupaten Cirebon yaitu sebanyak 70 responden. Sampel sebanyak 40 responden yang diambil secara purposive sampling. Instrumen penelitian yang digunakan pada penelitian ini adalah panduan SPO Konseling Personal dan kuesioner. Panduan SPO Konseling Personal adalah panduan untuk melaksanakan konseling personal, melalui wawancara berbentuk konseling. Adapun kuesioner yang di berikan yaitu kuisioner perilaku pencegahan penularan TB paru, untuk instrumen pengukuran perilaku pencegahan penularan oleh klien TB paru dibuat sesuai dengan indikatorindikator perilaku pencegahan penularan TB paru. Analisa univariat pada penelitian ini menggunakan statistik deskriptif meliputi jumlah, rata-rata (mean), median, modus dan standar deviasi. Dalam penelitian ini analisa bivariat menggunakan uji statistik paired T-test.

\section{HASIL}

\section{Perilaku Pencegahan Penularan Penderita TB Paru Sebelum diberikan Konseling Personal}

Tabel 1. Perilaku pencegahan penularan responden penderita TB sebelum diberikan konseling personal

\begin{tabular}{ccc}
\hline Perilaku Pencegahan Penularan & $\mathrm{n}$ & Persentase $(\%)$ \\
\hline Rendah & 16 & 66,7 \\
Tinggi & 8 & 33,3 \\
\hline Total & 24 & 100 \\
\hline
\end{tabular}

Berdasarkan tabel 1 bahwa sebelum dilakukannya pemberian konseling personal, responden yang memiliki perilaku pencegahan penularannya rendah sebanyak $66,7 \%$.

\section{Perilaku Pencegahan Penularan Penderita TB Paru Setelah diberikan Konseling Personal}

Tabel 2. Perilaku pencegahan penularan responden penderita TB setelah diberikan konseling personal

\begin{tabular}{ccc}
\hline Perilaku Pencegahan Penularan & $\mathrm{n}$ & Persentase $(\%)$ \\
\hline Rendah & 0 & 0 \\
Tinggi & 24 & 100 \\
\hline Total & 24 & 100 \\
\hline
\end{tabular}

Tabel 2 menunjukan bahwa perilaku pencegahan penularan responden penderita TB paru setelah diberikan konseling personal seluruhnya yaitu 24 orang (100\%) memiliki perilaku pencegahan penularan tinggi.

\section{Pengaruh Konseling Personal Terhadap Perilaku Pencegahan penularan TB paru}

Tabel 3. Pengaruh Konseling Personal Perilaku Perilaku Pencegahan penularan TB paru 


\begin{tabular}{cccc}
\hline Variabel & Nilai Rata-rata & Selisih & P value \\
\cline { 1 - 2 } Pre-test & 11,25 & & \\
\hline Post-test & 20,83 & 9,58 & 0,000 \\
\hline
\end{tabular}

Tabel 3 menampilkan hasil uji statisik pada pre-tes diperoleh rata-rata 11.25 dan pada posttes diperoleh rata-rata 20.83 di Wilayah Kerja UPT Puskesmas Plumbon Kabupaten Cirebon Tahun 2019.

\section{PEMBAHASAN}

\section{Perilaku Pencegahan Penularan Penderita TB Paru Sebelum diberikan Konseling Personal}

Hasil penelitian terlihat bahwa persentasi perilaku pencegahan penularan pada penderita TB paru didapatkan hasil yang rendah yaitu $66,7 \%$ berjumlah 16 responden, dilihat ketika berperilaku batuk atau bersin tidak menutup mulut dengan alat seperti sapu tangan begitu juga ketika membuang dahak atau ludah yang tidak tempat yang sesuai atau tertutup, padahal sumber penularan TB paru terdapat pada dahaknya yang mengandung kuman TB paru. Hal ini dapat dikatakan bahwa masih ditemukan responden dengan perilaku pencegahan penularan dengan kategori rendah. Maka dari itu diperlukan pemberian konseling personal sebagai salah satu upaya untuk meningkatkan perilaku pencegahan penularan oleh penderita TB paru. Dalam hal ini penelitian ini masih ditemukan responden dengan perilaku pencegahan penularan dengan kategori rendah. Maka dari itu masih diperlukan pemberian konseling personal sebagai salah satu upaya untuk meningkatkan perilaku pencegahan penularan oleh penderita TB paru.

Perilaku manusia merupakan semua aktivitas manusia baik yang bisa diamati maupun yang tidak diamati oleh orang lain. ${ }^{8}$ Perilaku individu tidak muncul sendirinya, namun perilaku muncul akibat adanya rangsangan dari dalam diri atau dari luar individu. Berdasarkan definisi diatas, perilaku pencegahan penularan TB paru adalah perilaku kesehatan individu atau klien yang bertujuan untuk mencegah timbulnya penyakit TB paru. ${ }^{8}$

\section{Perilaku Pencegahan Penularan Penderita TB Paru Sesudah diberikan Konseling Personal}

Hasil penelitian menunujukan setelah diberikan konseling personal, perilaku pencegahan penularan oleh pasien TB paru meningkat seluruhnya dari dari fakrtor ketidaktahuan tentang cara perilaku pencegahn penularannya menjadi tahu, tidak meludah sembarangan melainkan pada tempat yang disediakan atau tertutup dan dari sebelumnya belum menutup mulut atau bersin ketika batuk menjadi menjadi lebih baik dengan menggunakan alat atau sapu tangan.

Berdasarkan hasil nilai penelitian perilaku pencegahan penularan setelah diberikan konseling personal adalah 24 atau 100\% nilai tersebut merupakan dari jumlah total nilai tertinggi. Nilai yang didapat setelah diberikan konseling personal lebih besar dari nilai sebelum diberikan intervensi konseling personal. Hal ini disebabkan adanya pemberian intervensi melalui konseling personal dengan ini akan memberikan pengaruh pada peningkatan perilaku pencegahan penularan penderita TB paru.

Juga sejalan dengan penelitian yang dilakukan Ninik Murtiyani (2014) tentang efektifitas konseling terhadap motivasi mencegah penularan TB Paru di Wilayah Puskesmas Sooko Mojokerto. Hasil penelitian ini didapatkan nilai rata-rata motivasi sebelum perlakuan (konseling) yaitu 52.66<68.00. Data mean/nilai rata-rata ini menunjukan bahwa motivasi sebelum melakukan perlakuan (konseling) kurang baik dibanding sesudah perlakuan (konseling).

\section{Pengaruh Konseling Personal Perilaku Perilaku Pencegahan penularan TB paru}

Data penelitian menunjukan bahwa sebagian besar perilaku pencegahan penularan TB paru sebelum diberikan konseling personal sebanyak 24 responden di dapatkan hasil rata-rata 11,25 setelah diberikan 20,83 dengan nilai probabilitas ( $p$ value) sebeasr 0,000 sehingga kesimpulan uji statistik adalah terdapat pengaruh pemberian konseling personal terhadap perilaku pencegahan penularan TB paru di Wilayah Kerja UPT Puskesmas Plumbon Kabupaten Cirebon tahun 2019. 
Hal ini menunjukan bahwa perilaku pencegahan penularan TB paru pasca pemberian konseling terjadi perubahan.

Rata-rata nilai pre-test dan post-test tersebut terdapat perubahan atau kenaikan rata-rata nilai pre-test ke rata-rata nilai post-test. Peningkatan perilaku pencegahan penularan TB paru dikarenakan responden telah menerima informasi tentang pencegahan penularan TB paru melalui proses konseling personal. Adanya konseling personal dapat membantu penderita TB paru untuk memahami bahaya penularan TB paru.

Penelitian ini sesuai dengan penelitian yang dilakukan oleh Duriana Mara Majara (2018), bahwa hasil penelitian membuktikan sebagian besar responden (80\%) memiliki kesadaran TB Paru sesudah diberikan konseling personal di Wilayah Puskesmas Janti Kota Malang dengan $p$-value $(0,000<0,050)$. Dari hal ini membuktikan bahwa konseling personal terbukti efektif dalam memperbaiki perilaku pencegahan penularan TB Paru. Melalui pendekatan konseling personal diharapkan proses edukasi lebih intens, sehingga hasil yang didapatkan tidak sebatas transfer informasi, tetapi juga dapat merubah perilaku penderita TB Paru agar berperilaku hidup sehat.

\section{SIMPULAN}

1. Perilaku pencegahan penularan penderita TB paru yang menjadi sampel dalam penelitian ini sebelum diberikan konseling personal, 16 orang $(66,7 \%)$ katagori perilakunya pencegahan penularan rendah dan 8 orang $(33,3 \%)$ berperilaku pencegahan penularan tinggi.

2. Perilaku pencegahan penularan penderita TB paru yang menjadi sampel dalam penelitian ini setelah diberikan konseling personal seluruh sampel yaitu 24 orang (100\%) berperilaku pencegahan penularan tinggi.

3. Hasil analisis data dengan menggunakan uji statistik parametrik Paired $T$ test diperoleh nilai $p$ value $=0,000$ artinya terdapat pengaruh konseling personal terhadap perilaku pencegahan penularan TB paru

\section{SARAN}

1. Bagi Institusi Pendidikan (STIKes Cirebon)

Memberikan pendidikan dan pengajaran kepada peserta didik terutama dalam hal komunikasi terapeutik berupa konseling yang bersifat sederhana dan aplikatif sehingga saat dipraktekan memudahkan peserta didik, disamping itu pula berperan serta mengedukasi peserta didik dan masyarakat dengan dibuatnya media-media dalam bentuk brosur dan lain-lain tentang penyakit TB paru

2. Bagi Peneliti

Bagi peneliti, penelitian ini dijadikan sebagai penerapan kegiatan yang berguna dalam bidang keperawatan. Peneliti menyadari bahwa hasil penelitian ini bukanlah yang sempurna. Jadi perlu adanya peningkatan bagi peneliti selanjutnya agar memperoleh hasil yang sempurna, terutama mengenai penerapan kegiatan konseling personal di Puskesmas.

3. Bagi UPT Puskesmas Plumbon

Berdasarkan hasil penelitian menunjukan bahwa konseling personal dapar mempengaruhi perilaku pencegahan penularan TB paru pada penderita TB paru di Wilayah Kerja UPT Puskesmas Plumbon Kabupaten Cirebon. Penelitian ini diharapkan dapat dijadikan informasi dalam penerapan kegiatan konseling personal di Puskesmas.

4. Bagi Responden

Pasien memahami bahwa penyakit TB paru menular dan berbahaya sehingga harus betul-betul mematuhi dan melaksanakan anjuran-anjuran tenaga kesehatan saat konseling individu/ masal di puskesmas atau di sarana kesehatan lainnya dalam hal kepatuhan minum obat, tidak membuang dahak/meludah sembarangan, menutup mulut dengan tisu/sapu tangan saat bersin dan lain-lain yang dapat menimbulkan penularan kepada keluarganya atau orang-orang yang dekat dengannya. 


\section{DAFTAR PUSTAKA}

1. Nizar, Muhamad. Pemberantasan dan penanggulangan tuberculosis. Yogyakarta: Gosyen publishing; 2017

2. Informasi Kementrian Kesehatan RI Direktorat. Pencegahan dan penanggulangan penyakit: Kebijakan program penanggulangan tuberkulosis [e-book]. Jakarta: 2017 [diakses tanggal 5 Desember 2018]. Tersedia dari: http//modul kebijakan penanggulangan tb.pdf

3. Perkumpulan Pemberantasan Tuberkulosis Indonesia (PPTI): Buku saku tb [e-book]. Jakarta: 2010 [diakses: 4 Desember 2018]. Tersedia dari: http//www.PPTI.info

4. Dinas Kesehatan Provinsi Jawa Barat: Profil kesehatan Jawa Barat [e-book]. Jawa Barat:2016 [diakses: 6 Desember 2018]. Tersedia: http//12_Jabar_2016_1.pdf

5. Prayitno. Erman Ati. Dasar dasar bimbingan dan konseling. Jakarta : PT Rineka Putra;2009

6. Corey.G. Teori dan praktek konseling dan psikoterapi. Bandung: PT. Refika Aditama;2009

7. Baradero, Mary. Konseling dalam keperawatan. Jakarta: EGC; 2006.

8. M. Luddin. Abu Bakar. Konseling individual dan kelompok (aplikasi dalam praktek konseling). Bandung: Cita Pustaka Media Perintis;2012 